\title{
APRESENTAÇÃO DO DOSSIÊ: "DISCURSOS E ITINERÁRIOS DE MODERNIZAÇÃO EDUCATIVA NO ESPAÇO LUSO-BRASILEIRO"
}

\author{
DOI: http://dx.doi.org/10.1590/2236-3459/71702 \\ DISCOURSES AND ITINERARIES OF EDUCATIONAL MODERNIZATION \\ IN PORTUGUESE AND BRAZILIAN SPACE
}

Organização:

Giana Lange do Amaral

Universidade Federal de Pelotas (Ufpel), Brasil

Mauro Castilho Gonçalves

Pontifícia Universidade Católica de São Paulo (PUC/SP), Brasil

Universidade de Taubaté (Unitau), Brasil

$\cos 80$

de pertencimento e sociabilidade, com conexões luso-brasileiras. O resultado dessa articulação é expresso na produção de livros e artigos, viabilizado por iniciativas institucionalizadas de estudos, assim como contatos pessoais e profissionais. Os textos elencados neste dossiê resultam de discussões oriundas da apresentação de trabalhos no Congresso Luso Brasileiro de História da Educação, realizado em 2016, na cidade do Porto, em Portugal.

As investigações aqui sistematizadas remetem ao período em que os autores Teresa Rosa, que é portuguesa, e os brasileiros Raylane Barreto, Mauro Gonçalves e Giana Amaral, realizaram o estágio pós-doutoral, na Universidade de Lisboa, sob orientação de Justino Magalhães. Constituiu-se, no ano de 2014, um grupo que tinha na 
modernização educativa uma temática comum em suas pesquisas. Nos artigos aqui apresentados, foram analisados documentos arquivados na Biblioteca Nacional de Portugal, na Torre do Tombo e em diferentes acervos documentais lusitanos e brasileiros.

A compreensão dos dilemas da modernidade e dos processos de modernização no âmbito educacional tem desafiado pesquisadores. Ainda mais se levarmos em conta a afirmativa de Justino Magalhães (2010, p. 11) de que "na base da Modernidade está a educação". A educação aqui tomada pelo autor, como sinônimo de pessoalização; etimologicamente remetida a educare e/ou educere: "acção de alimentar, desenvolver e criar, ou a acção de conduzir e fazer sair. O sentido de transformação, ou seja, uma sucessão de quase-metamorfose está presente no conceito de educação".

Assim, o dossiê Discursos e Itinerários de Modernização Educativa no Espaço Luso-brasileiro constitui um meio de investigação, conceptualização e discussão. Incide numa temática aberta, modernização educativa, que será extensiva ao Ocidente Moderno e Contemporâneo, a partir de uma perspectiva histórico-comparada entre Portugal e Brasil. O tempo longo e a representação sob a modalidade de discursos e itinerários permitem mapear diversos assuntos, espaços e quadros de modernização educativa. $\mathrm{O}$ compromisso de partida entre o conjunto de investigadores: a partilha de uma metodologia comum, associada à História Cultural. A incidência em discursos e itinerários meta-educativos de teor reformista possibilitam um contributo substantivo para a História da Educação. É proposto um ensaio paradigmático resultante da congregação de um tema, de uma conceptualização que reúne um grupo de produção com um quadro histórico-educativo de referência.

O artigo de Teresa Rosa, A Matriz Pedagógica Jesuíta e a Sistemática Escolar Moderna, trata da Ratio Studiorum, texto fundador de ordenação e sistematização de estudos, que permitiu o desenvolvimento de um sistema escolar de alcance internacional. A autora evidencia a possível atualidade de algumas das características dessa metodologia jesuítica, que podem ainda a vir contribuir para que o aluno participe com mais empenho no processo ensino-aprendizagem. Sublinha a potencialidade da Ratio Studiorum na inspiração para o trabalho educativo nos tempos atuais, uma vez que se centra no encontro pessoal entre o educador e o educando, num processo contínuo de interação e comunicação.

Raylane Barreto, em seu artigo Tobias Barreto de Menezes e a Educação para um Brasil Moderno (Séc. XIX), ressalta a importância da abordagem da história de intelectuais para a compreensão de aspectos da História da Educação. Assim, destaca ideias, propostas e práticas de Tobias Barreto de Menezes, um dos autores expoentes dos oitocentos brasileiro, relacionando-as com questões educacionais do período, em especial no nordeste brasileiro. Nesse sentido, a análise empreendida busca articular as principais expressões desse autor, que teve o germanismo como "linha inspiradora" germanismo este, que se revelou em diversas frentes de sua produção bibliográfica - em prol da educação superior feminina e da educação para o trabalho com vistas a um Brasil moderno. A autora conclui que a concepção de Tobias Barreto mais do que partir da crítica a todos os membros da hierarquia social do império, contempla a missão do homem de ciência para a qual, segundo Weber, a visão de mundo permite apresentar padrões morais e éticos e a ciência se torna uma instância mediadora da vida.

O artigo de Giana Lange do Amaral, Os maçons e a Modernização Educativa no 
Brasil no Período de Implantação e Consolidação da República, parte da premissa de que a atuação de maçons e da maçonaria no contexto educacional brasileiro ainda é uma temática pouco estudada. Nesse sentido, a autora destaca encaminhamentos de um estudo maior sobre a influência de maçons no processo de modernização educacional que se consolida entre as últimas décadas do século XIX e primeiras do século XX. A atuação de maçons, respaldada por idéias liberais e iluministas, se consolida nas primeiras décadas do regime republicano, influenciada pelo ideário positivista e antijesuítico, em defesa do ensino elementar público, laico e obrigatório. No Brasil, a Maçonaria adaptou-se às condições específicas e necessidades regionais de onde se instalou. Portanto ela não deve ser compreendida num sentido unívoco, sendo mais fácil identificar a ação e engajamento ideológico de maçons e não da Maçonaria propriamente dita. Este artigo, fundamentado pela História Cultural, privilegia o uso de periódicos maçônicos e busca destacar práticas políticas dos maçons como intelectuais, gestores, legisladores, escritores, jornalistas e professores, bem como as Lojas Maçônicas como potenciais espaços de sociabilidades e organização ideológica.

Mauro Castilho Gonçalves, no artigo Integralismo Lusitano e Educação Católica: Conexões entre Intelectuais e o Caso do Colégio Vasco da Gama de Lisboa, Portugal (década de 1920) apresenta, inicialmente, as fontes e problematizações que nortearam a temática abordada, particularmente as que versam sobre as conexões entre o Integralismo Lusitano (IL) e o campo escolar. $\mathrm{O}$ autor examina o projeto cultural e pedagógico do colégio lisboeta Vasco da Gama, instituição de ensino fundada em 1915, que pretendeu instruir e educar seus alunos sob as bases da Educação Física, da Religião e das Artes, à luz da doutrina católica, dos princípios integralistas e de uma rígida disciplina interna. Seu estudo tem como fonte central de investigação um periódico, criado em meados dos anos de 1920. Ele serviu de base na configuração do projeto cultural do colégio e expressão institucionalizada de uma rede de sujeitos conectados e ativos em tempos conturbados da política portuguesa. Alcançar os estudantes secundaristas e universitários era uma das metas do IL. Seguindo os preceitos doutrinários do IL, estava destinado à juventude escolar e acadêmica um papel na luta pela regeneração da alma portuguesa, por meio da restauração monárquica.

Pelo que foi exposto, o leitor pode perceber que há, entre os trabalhos apresentados, linhas comuns no modo de abordagem sobre um mesmo tema, mas há também o objetivo de mostrar como a modernização educativa sofre metamorfoses discursivas tendo sido alocada em diferentes espaços, movimentos e ideários. É uma temática de História Cultural, centrada nos movimentos de intelectuais e de transformação social e institucional. A modernização educativa em Portugal e Brasil é aqui inventariada e referenciada em distintos tempos históricos, assuntos, autores e pensadores.

\section{Referência}

MAGALHÃES, J. Da cadeira ao banco: escola e modernização (séculos XVIII-XX). Lisboa: EDUA, Unidade de I\&D de Ciências da Educação, 2010. 
GIANA LANGE DO AMARAL é professora do Programa de Pós-Graduação em Educação da Universidade Federal de Pelotas, pesquisadora CNPq/PQ2, Doutora em Educação pela Universidade Federal do Rio Grande do Sul, com estágio Pós-doutoral na Universidade de Lisboa e na PUC/RS.

Endereço: Rua Três de Maio, 973 - 96010-620 - Pelotas/RS, Brasil.

E-mail: gianalangedoamaral@gmail.com

MAURO CASTILHO GONÇALVES é professor do Programa de Estudos Pós-Graduados em Educação: História, Política, Sociedade da Pontifícia Universidade Católica de São Paulo e da Universidade de Taubaté, SP. Doutor em Educação: História, Política, Sociedade pela PUC-SP.

Endereço: Rua Brigadeiro Galvão, 436, ap. 147 - 01151-000 - São Paulo/SP - Brasil. E-mail: mauro_castilho@uol.com.br

Recebido em 06 de março de 2017.

Aceito em 10 de abril de 2017. 